\title{
Microstructure and mechanical properties of laser additive manufactured novel titanium alloy after heat treatment
}

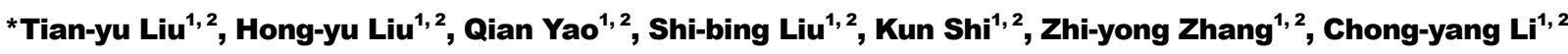 \\ 1. Shenyang Research Institute of Foundry Co., Ltd., Shenyang 110022, China \\ 2. State Key Laboratory of Light Alloy Casting Technology for High-end Equipment, Shenyang 110022, China
}

\begin{abstract}
A novel $\alpha+\beta$ titanium alloy with multi-alloying addition was designed based on the cluster formula 12[Al-Ti $\left.{ }_{12}\right]\left(\mathrm{AlTi}_{2}\right)+5\left[\mathrm{Al}^{\left.-\mathrm{Ti}_{14}\right]}\left(\mathrm{AlV}_{1.2} \mathrm{Mo}_{0.6} \mathrm{Nb}_{0.2}\right)\right.$ which was derived from Ti-6Al-4V. The nominal composition of this novel alloy was determined as Ti-6.83Al-2.28V-2.14Mo-0.69Nb-6.79Zr. In this study, the novel alloy and Ti-6Al-4V alloy samples were prepared by laser additive manufacturing. The microstructure, micro-hardness, room/high temperature tensile properties of the as-deposited samples were investigated. Compared to Ti-6Al-4V, the novel alloy has much higher room and high temperature $\left(600{ }^{\circ} \mathrm{C}\right)$ tensile strengths, which are $1,427.5 \mathrm{MPa}$ and $642.2 \mathrm{MPa}$, respectively; however, it has a much lower elongation $(3.2 \%)$ at room temperature because of the finer microstructure. To improve the elongation of the novel alloy, heat treatment was used. After solution at $960{ }^{\circ} \mathrm{C}$ or $970{ }^{\circ} \mathrm{C}$ for $1 \mathrm{~h}$ followed by air cooling and aging at $550^{\circ} \mathrm{C}$ for $4 \mathrm{~h}$ followed by air cooling, a unique bi-modal microstructure which contains crab-like primary $\alpha$ and residual $\beta$ phase is obtained, improving the compression elongation by $80.9 \%$ compared to the as-deposited samples. The novel alloy can be used as a high-temperature and high-strength candidate for laser additive manufacturing.
\end{abstract}

Key words: laser additive manufacturing; titanium alloy; composition design; heat treatment
CLC numbers: TG146.23
Document code: A
Article ID: 1672-6421(2021 06-574-07

\section{Introduction}

Titanium alloys are widely used in aerospace, chemistry, automobile, and biomedical fields due to their high specific strength, low density, excellent corrosion resistance, and biocompatibility ${ }^{[1]}$. However, the preparation of titanium alloys by traditional methods (including casting, wrought, rolling) has a great challenge because of their high chemical reactivity and poor thermal conductivity ${ }^{[2,3]}$. Laser additive manufacturing (LAM) by an incremental layerby-layer processing method with the characteristic of near net shaping, cost-effectiveness, and unrivalled design freedom has attracted much attention ${ }^{[4,5]}$. In contrast with the part produced by traditional methods, experiencing melting and solidification in a very short time, LAM part has a unique microstructure and mechanical properties, but most industrial titanium

\footnotetext{
*Tian-yu Liu

Male, $\mathrm{Ph}$. D. His research interests mainly focus on titanium alloys design and laser additive manufacturing.

E-mail: liutianyusrif@163.com

Received: 2021-06-28; Accepted: 2021-11-11
}

alloys are unsuitable for LAM.

Since the application of Ti-6Al-4V in LAM, many titanium alloys have been designed for LAM ${ }^{[6-9]}$. Mendoza et al. ${ }^{[7]}$ deposited Ti- $x \mathrm{~W}$ alloys by LAM, and the result indicated that $\mathrm{W}$ could refine the microstructure. Zhang et al. ${ }^{[8]}$ studied the microstructure and mechanical properties of Ti-2Al-xMo alloys by LAM. The results showed that a tendency towards columnar-to-equiaxed transition with increasing $\mathrm{Mo}$, and Ti-2Al-7Mo exhibited a good combination of strength and elongation. To address the problem of anisotropy, Zhang et al. ${ }^{[9]}$ reported on the development of Ti$\mathrm{Cu}$ alloys with a high constitutional supercooling capacity, leading to a fully equiaxed fine-grained microstructure. However, the above alloys suitable for LAM were statistically obtained via a large number of experimental data, there is a lack of composition design methods to quantitatively develop novel alloys.

Alloys with excellent properties all have specific chemical compositions, characterized by the chemical short-range ordering. Therefore, establishing the chemical short-range ordering of special compositions is significant to shorten the development time of 
novel alloys. Fortunately, the chemical short-range ordering can be described by the cluster-plus-glue atom model which covers only a nearest-neighbor cluster and some glue atoms situated outside the cluster, which can be represented as cluster formula "[cluster](glue atoms) ${ }_{x}$ " ${ }^{[10]}$. The occupations of solution elements in the cluster formula are determined by the enthalpy of mixing $(\Delta H)$ between the solute and solvent elements ${ }^{[11]}$. The $\beta$ phase cluster of Ti- $6 \mathrm{Al}-4 \mathrm{~V}$ contains the solution elements $\mathrm{Al}$ and $\mathrm{V}, \mathrm{Al}$ occupying the central position due to its strong interaction with $\operatorname{Ti}\left(\Delta H_{\mathrm{Ti}-\mathrm{Al}}=-30 \mathrm{~kJ} \cdot \mathrm{mol}^{-1}\right)$, and $\mathrm{V}$ occupying the glue atom position due to its weak interaction with $\mathrm{Ti}\left(\Delta H_{\mathrm{Ti}-\mathrm{V}}=-2 \mathrm{~kJ} \cdot \mathrm{mol}^{-1}\right)$, so the cluster formula [Al- $\left.\mathrm{Ti}_{14}\right]$ $\left(\mathrm{V}_{2} \mathrm{Ti}\right)$ is formed. Similarly, the $\alpha$ phase cluster formula of Ti-6Al-4V is $\left[\mathrm{Al}-\mathrm{Ti}_{12}\right]\left(\mathrm{AlTi}_{2}\right)$. Then, the $\alpha$ and $\beta$ clusters are treated as hard spheres of different radii and packed according to the cluster-plus-glue-atom model. Calculations determined that the cluster formula of Ti-6Al-4V alloy was $12\left[\mathrm{Al}^{-\mathrm{Ti}_{12}}\right]$ $\left(\mathrm{AlTi}_{2}\right)+5\left[\mathrm{Al}-\mathrm{Ti}_{14}\right]\left(\mathrm{V}_{2} \mathrm{Ti}\right)$ by previous study ${ }^{[12]}$.

Heat treatments turn out to be the most promising way to improve comprehensive mechanical properties of novel alloys. Vrancken et al. ${ }^{[13]}$ demonstrated that the elongation of LAM Ti-6Al-4V alloy was increased from $7 \%$ to $13 \%$ by annealing at $850{ }^{\circ} \mathrm{C}$ for $2 \mathrm{~h}$ followed by furnace cooling. Zhao et al. ${ }^{[14]}$ reported that the elongation of LAM Ti-6Al-4V alloy was improved observably to $25 \%$ by the triple heat treatment. Besides that, Ren and Liu et al. ${ }^{[15,16]}$ got similar results.

In this study, the novel $\alpha+\beta$ titanium alloy Ti-6.83Al-2.28V2.14Mo-0.69Nb-6.79Zr was designed based on the Ti-6Al-4V cluster formula, and fabricated by LAM. The microstructure, micro-hardness, room temperature and high temperature tensile, and compress properties of as-deposited and heattreated samples were investigated.

\section{Experimental procedures}

\subsection{Composition design}

In our previous work ${ }^{[12]}$, it was found that being independent of the annealing temperature, the $\alpha$ phase cluster formula [A1$\left.\mathrm{Ti}_{12}\right]\left(\mathrm{AlTi}_{2}\right)$ of Ti-6Al-4V maintained constant. However, the $\beta$ phase cluster formula, changing drastically as the annealing temperature changed, was $\left[\mathrm{Al}-\mathrm{Ti}_{14}\right]\left(\mathrm{V}_{3}\right)$ at $700{ }^{\circ} \mathrm{C},\left[\mathrm{Al}-\mathrm{Ti}_{14}\right]\left(\mathrm{V}_{2} \mathrm{Ti}\right)$ at $800{ }^{\circ} \mathrm{C}$, and $\left[\mathrm{Al}-\mathrm{Ti}_{14}\right](\mathrm{AlVTi})$ at $950{ }^{\circ} \mathrm{C}$. As mentioned above, $\left[\mathrm{Al}-\mathrm{Ti}_{14}\right](\mathrm{AlVTi})$ was much more stable at high temperature. To improve room and high temperature strength, the basic cluster formula $12\left[\mathrm{Al}_{-} \mathrm{Ti}_{12}\right]\left(\mathrm{AlTi}_{2}\right)+5\left[\mathrm{Al}-\mathrm{Ti}_{14}\right](\mathrm{AlVTi})$ was established. Therefore, Ti-6.83Al-2.28V-2.14Mo-0.69Nb$6.79 \mathrm{Zr}$ (abbreviated as $7 \mathrm{Zr}$ alloy) was designed based on the cluster $12\left[\mathrm{Al}-\mathrm{Ti}_{12}\right]\left(\mathrm{AlTi}_{2}\right)+5\left[\mathrm{Al}-\mathrm{Ti}_{14}\right]\left(\mathrm{AlV}_{1.2} \mathrm{Mo}_{0.6} \mathrm{Nb}_{0.2}\right)$ by $\left(\mathrm{V}_{0.2} \mathrm{Mo}_{0.6} \mathrm{Nb}_{0.2}\right)$ replacing $\mathrm{Ti}$, because $\mathrm{Mo}$ and $\mathrm{Nb}$ have weak interactions with $\mathrm{Ti}\left(\Delta H_{\mathrm{Ti}-\mathrm{Mo}}=-4 \mathrm{~kJ} \cdot \mathrm{mol}^{-1}, \Delta H_{\mathrm{Ti}-\mathrm{Nb}}=2 \mathrm{~kJ} \cdot \mathrm{mol}^{-1}\right)$.

\subsection{Laser additive manufacturing}

Commercially pure $\mathrm{Ti}, \mathrm{Al}, \mathrm{V}, \mathrm{Mo}, \mathrm{Nb}$, and $\mathrm{Zr}$ powders, with particle size range of $75-150 \mu \mathrm{m}$, were mixed according to the alloy nominal compositions of Ti-6.83Al-2.28V-2.14Mo$0.69 \mathrm{Nb}-6.79 \mathrm{Zr}$ and $\mathrm{Ti}-6.05 \mathrm{Al}-3.94 \mathrm{~V}$ (as a reference alloy). Then, the bulk samples with a geometric size of $60 \mathrm{~mm} \times 25 \mathrm{~mm}$ $\times 15 \mathrm{~mm}$ were manufactured by the LAM system that consists of a $6 \mathrm{~kW} \mathrm{CO}$ laser, a four-nozzle coaxial powder feed system, a controlled environment glove box with an oxygen content less than $100 \mathrm{ppm}$, and a motion control system. The processing parameters were as follows: laser power $1,800 \mathrm{~W}$, scanning speed $480 \mathrm{~mm} \cdot \mathrm{s}^{-1}$, overlapping ratio $30 \%$, and Z-axis increment $0.6 \mathrm{~mm}$. The zigzag pattern scanning strategy was used, and the scanning path of each layer was the same.

\subsection{Heat treatment}

The $\beta$-transus temperature of the $7 \mathrm{Zr}$ alloy was between $970{ }^{\circ} \mathrm{C}$ and $980{ }^{\circ} \mathrm{C}$ via the metallographic method, as shown in Fig. 1. To investigate the effect of solution temperature on microstructure and mechanical properties, the solution treatment of $7 \mathrm{Zr}$ alloy was conducted with a KSL-1700X muffle furnace at $925^{\circ} \mathrm{C}, 945^{\circ} \mathrm{C}, 960{ }^{\circ} \mathrm{C}, 970{ }^{\circ} \mathrm{C}, 985^{\circ} \mathrm{C}$ and $995^{\circ} \mathrm{C}$ for $1 \mathrm{~h}$ followed by air cooling (AC), and then aged at $550{ }^{\circ} \mathrm{C}$ for $4 \mathrm{~h}$ followed by AC. The heat-treated samples were sealed in a vacuum quartz tube to prevent oxidation.

\subsection{Microstructure and mechanical properties analysis}

Phase constitution analysis was carried out by means of a BRUKER X-ray diffractometer (XRD) with a $\mathrm{Cu} \mathrm{K} \alpha$ radiation. Longitudinal metallographic samples of optical microscopy (OM) and scanning electron microscopy (SEM) were
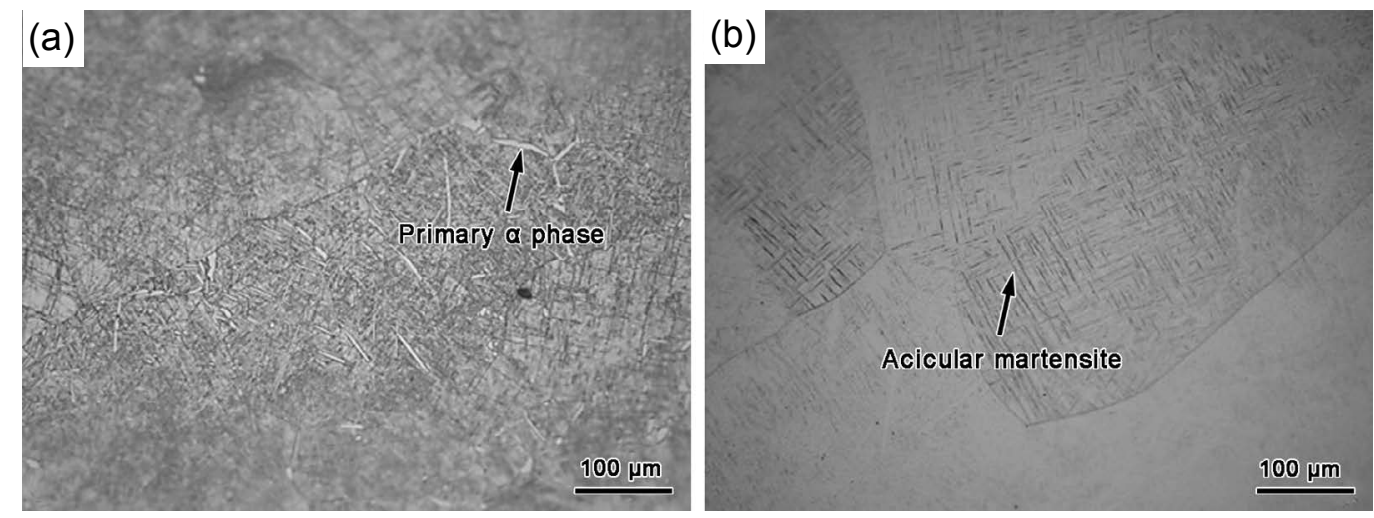

Fig. 1: OM images of $7 \mathrm{Zr}$ alloy after solution at $970^{\circ} \mathrm{C}$ (a) and $980^{\circ} \mathrm{C}$ (b) for $1 \mathrm{~h}$ followed by water quenching 
prepared by using a $\mathrm{SiC}$ grinding paper with 320 grit size, and polishing with a $\mathrm{SiO}_{2}-\mathrm{H}_{2} \mathrm{O}_{2}$ solution, and the etchant was $3 \% \mathrm{HF}+7 \% \mathrm{HNO}_{3}+90 \% \mathrm{H}_{2} \mathrm{O}$ (volume fraction). Quantitative measurements of the volume fraction, aspect ratio of primary $\alpha$, width of primary $\alpha$ and secondary $\alpha$ were conducted on at least three optical images for each sample by ImagePro software, and about 100 primary $\alpha$ and secondary $\alpha$ grains were measured, respectively.

Micro-hardness was tested by using HVS-1000 apparatus with a load of $300 \mathrm{~g}$ and a dwell time of $15 \mathrm{~s}$. Ten indents were measured at the polished surface. Uniaxial tensile and compressive tests of horizontal samples were conducted on an UTM5504-G electronic universal testing machine with a strain rate of $2.8 \times 10^{-4} \mathrm{~s}^{-1}$, in which the plate-shaped tensile samples with a gauge size of $49 \mathrm{~mm} \times 3.5 \mathrm{~mm} \times 2 \mathrm{~mm}$ (length $\times$ width $\times$ thickness) and cylinder-shaped compressive samples with a gauge size of $\Phi 3 \mathrm{~mm} \times 6 \mathrm{~mm}$.

\section{Results and discussion}

\subsection{As-deposited microstructure and mechanical properties}

Figure 2 shows the XRD patterns of the Ti-6Al-4V and $7 \mathrm{Zr}$ alloys. The XRD result suggests that Ti-6Al-4V and $7 \mathrm{Zr}$ alloys all contain $\alpha$ phase diffraction peaks with hexagonal closepacked (HCP) crystal structure. However, the major diffraction peaks (110) and (200) of $\beta$ phase are only detected in the $7 \mathrm{Zr}$ alloy, revealing the presence of $\beta$ phase with body-centered cubic $(\mathrm{BCC})$ crystal structure which depends on the $[\mathrm{Mo}]_{\mathrm{eq}}$.

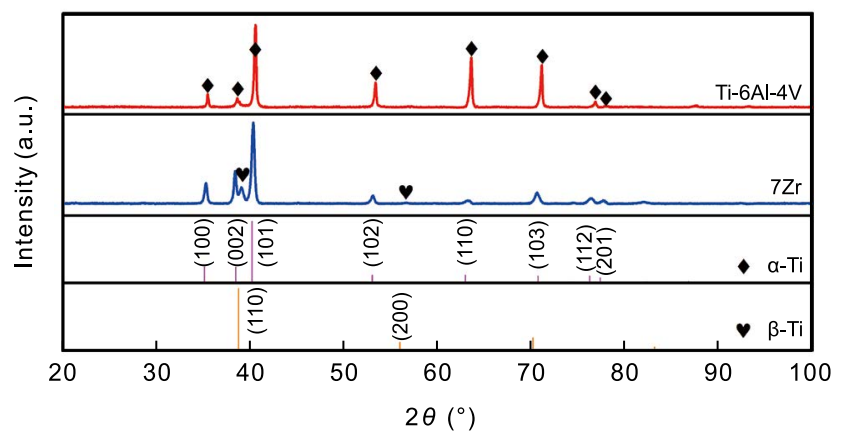

Fig. 2: XRD patterns of Ti-6AI-4V and $7 \mathrm{Zr}$ alloys

According to the equation of $[\mathrm{Mo}]_{\mathrm{eq}}{ }^{[17]}$ :

$$
\begin{aligned}
{[\mathrm{Mo}]_{\mathrm{eq}}=} & \mathrm{Mo}+\mathrm{Nb} / 3.3+\mathrm{Ta} / 4+\mathrm{W} / 2+\mathrm{Cr} / 0.6+\mathrm{Mn} / 0.6+\mathrm{V} / 1.4 \\
& +\mathrm{Fe} / 0.5+\mathrm{Co} / 0.9+\mathrm{Ni} / 0.8
\end{aligned}
$$

The $[\mathrm{Mo}]_{\mathrm{eq}}$ of $7 \mathrm{Zr}$ alloy $\left([\mathrm{Mo}]_{\mathrm{eq}}=3.97\right)$ is higher than that of Ti-6Al-4V $\left([\mathrm{Mo}]_{\mathrm{eq}}=2.84\right)$, which increases the volume fraction of residual $\beta$ phase due to improving $\beta$ stable capacity. Additionally, Hady-Abdel et al. ${ }^{[18]}$ confirmed that $\mathrm{Zr}$ was a weak $\beta$ phase stable element. Therefore, the XRD pattern of $7 \mathrm{Zr}$ alloy presents the $\beta$ phase diffraction peaks due to the high-volume fraction of $\beta$ phase. Besides that, compared to Ti- $6 \mathrm{Al}-4 \mathrm{~V}$, the peaks of $\alpha$ phase of the $7 \mathrm{Zr}$ alloy are slightly moved to the left, improving solution strengthening.

The microstructure characteristic of as-deposited Ti-6Al-4V and $7 \mathrm{Zr}$ alloys is prior- $\beta$ columnar grains which extend over multiple layers along the deposition direction, as shown in Figs. 3(a) and (b). These epitaxial columnar grains are attributed to partial remelting of previously deposited layers.
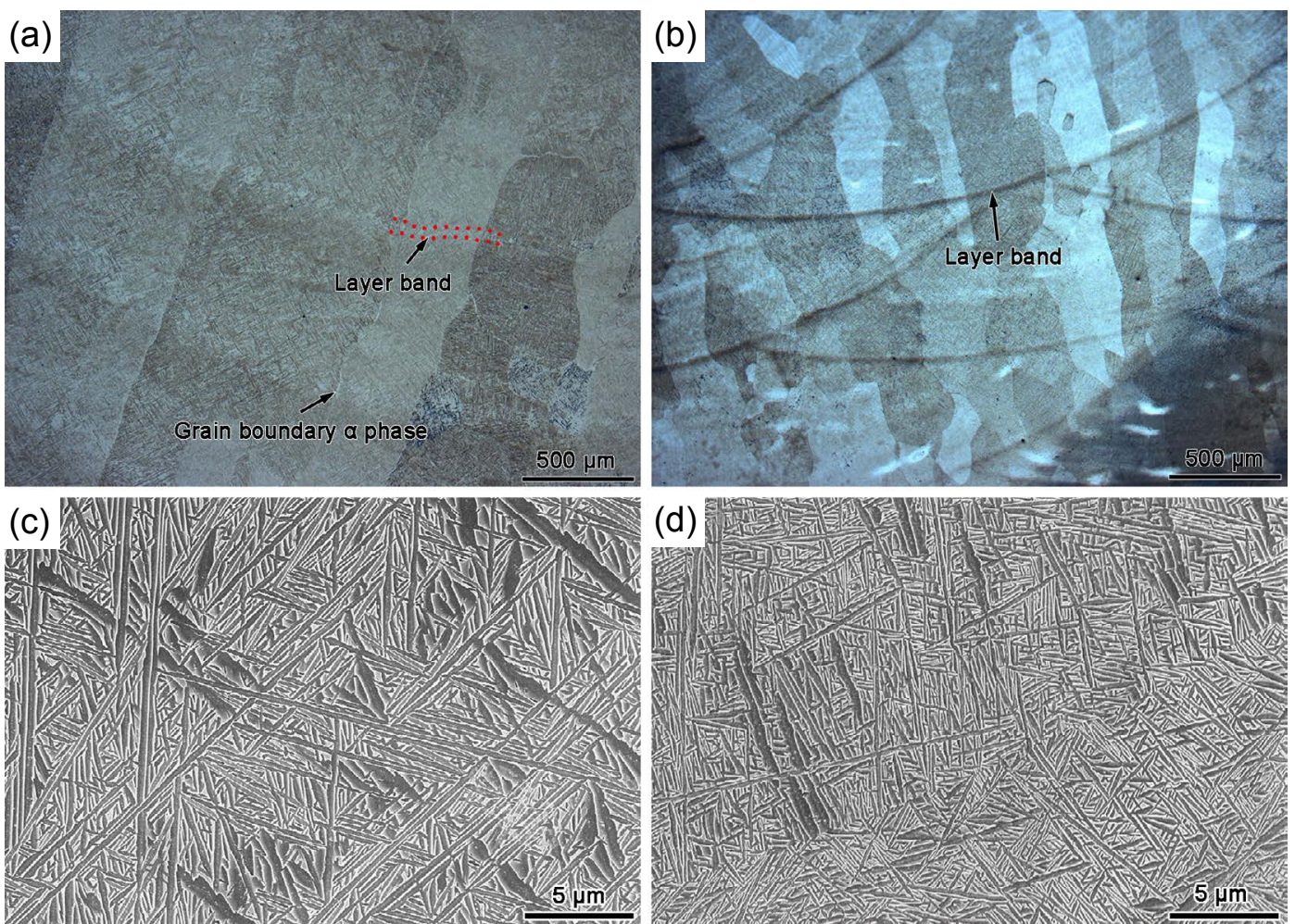

Fig. 3: Microstructure of Ti-6Al-4V and 7Zr alloys: (a, c) Ti-6Al-4V alloy; (b, d) 7Zr alloy 
Large columnar grains are formed due to the directional solidification which heat loss via the substrate or deposited layers is more rapid than via convection and radiation ${ }^{[19,20]}$. The width of prior- $\beta$ columnar grains of Ti- $6 \mathrm{Al}-4 \mathrm{~V}$ is $331 \mu \mathrm{m}$, while $7 \mathrm{Zr}$ alloys have finer grains $(155 \mu \mathrm{m})$. Furthermore, the microstructure within the columnar grains consists of basketweave $\alpha$-lath in both Ti-6Al-4V and $7 \mathrm{Zr}$ alloys, as shown in Figs. 3(c) and (d). The width of $\alpha$-lath is $0.27 \mu \mathrm{m}$ in Ti-6Al-4V and $0.15 \mu \mathrm{m}$ in $7 \mathrm{Zr}$ alloy, measured by ImagePro software. Due to the top of the pre-existing layer being reheated when the next layer is deposited, the grains in this region are coarsened causing the formation of a layer band.

Figure 4 shows the engineering tensile stress-strain and work hardening rate curves for Ti-6Al-4V and $7 \mathrm{Zr}$ alloys at room temperature. As shown in Fig. 4(a), the ultimate tensile stress (UTS) and yield stress (YS) of 7Zr equal 1,427.5 MPa and 1,356.6 MPa, which are much higher than Ti-6Al-4V which has UTS and YS of 976.9 MPa and 911.2 MPa, respectively. However, the higher strength is the trade-off for a lower elongation, and the elongation of $7 \mathrm{Zr}$ alloy is $3.2 \%$ which is much lower than that of Ti-6Al-4V (10.4\%). Furthermore, the stress-strain curve of Ti-6Al-4V displays no work hardening, but the work hardening rate curve of $7 \mathrm{Zr}$ alloy exhibits multistage work hardening behavior, as shown in Fig. 4(b). The work hardening rates of Ti-6Al-4V and $7 \mathrm{Zr}$ alloy decrease sharply in the early stage of deformation (Stage A). The sharp drop of work hardening is suppressed, slightly increasing with greater strain (Stage B) of $7 \mathrm{Zr}$ alloys. In general, work hardening in material is indicative of dislocation density ${ }^{[21]}$. As the width of $\alpha$-lath is smaller in $7 \mathrm{Zr}$ alloy than Ti-6Al-4V alloy, the dislocation density is increased, which hinders cross slip and thereby, recover the dislocations. Therefore, $7 \mathrm{Zr}$ alloy still has a certain degree of elongation under the condition of high strength. (a)

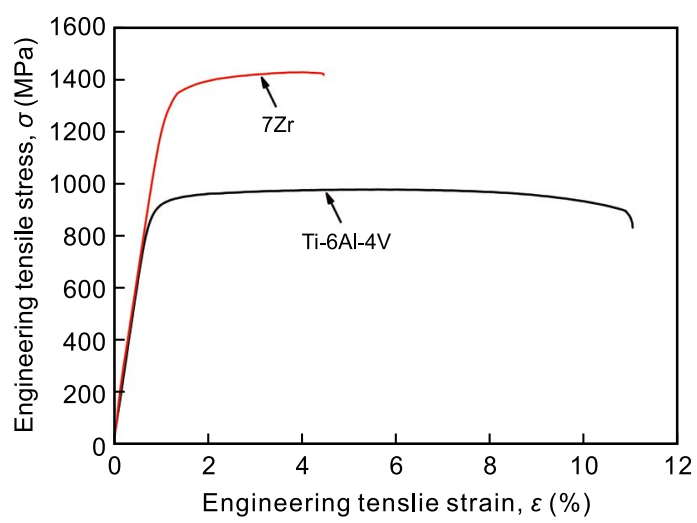

(b)

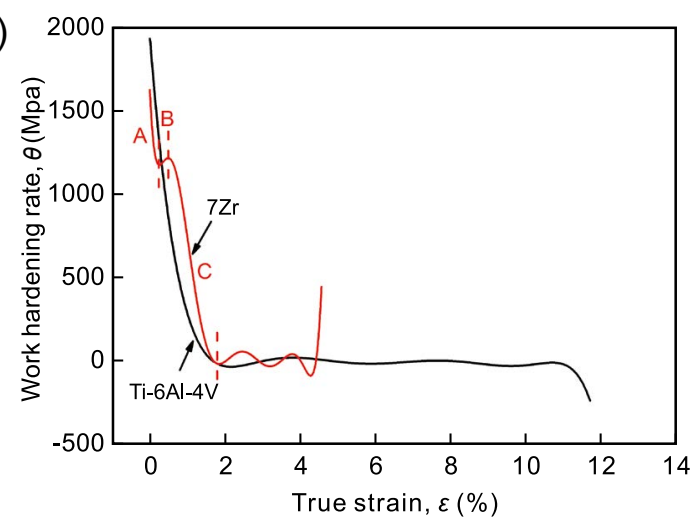

Fig. 4: Engineering tensile stress-strain (a) and work hardening rate (b) curves for Ti-6Al-4V and 7Zr alloys at room temperature

Figure 5 shows engineering tensile stress-strain curves for Ti-6Al-4V and $7 \mathrm{Zr}$ alloys at $600{ }^{\circ} \mathrm{C}$. As it can be seen, the stress-strain curves of Ti-6Al-4V and $7 \mathrm{Zr}$ alloys exhibit no work hardening. The UTS and YS of $7 \mathrm{Zr}$ alloys equal 642.2 $\mathrm{MPa}$ and 565.1 MPa, respectively, and the elongation is $41.5 \%$. By contrast, Ti-6Al-4V has a lower UTS and YS, namely $435.4 \mathrm{MPa}$ and $390.9 \mathrm{MPa}$, respectively, and the

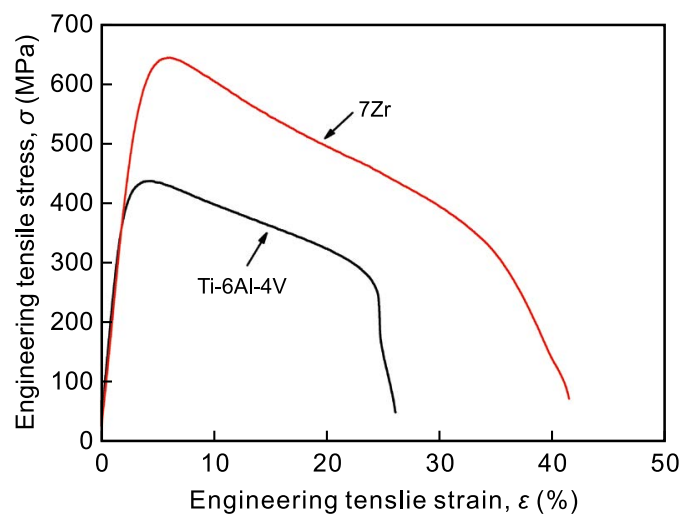

Fig. 5: Engineering stress-strain curves for Ti-6AI-4V and $7 Z$ r alloys at $600{ }^{\circ} \mathrm{C}$ elongation, equal to $26.1 \%$, is still remarkably lower than that of $7 \mathrm{Zr}$ alloys.

According to the Hall-Petch equation ${ }^{[22,23]}$ which describes the relationship between the strength and the grains size:

$$
\sigma_{\mathrm{Y}}=\sigma_{0}+k d^{-1 / 2}
$$

Where $\sigma_{\mathrm{Y}}$ is the yield strength, $\sigma_{0}$ and $k$ are material constants, and $d$ is the grains diameter. The equation suggests that the finer prior- $\beta$ columnar grains and $\alpha$-lath in $7 \mathrm{Zr}$ alloys can improve the YS. In addition, the $7 \mathrm{Zr}$ alloys with alloying elements $\mathrm{V}, \mathrm{Mo}, \mathrm{Nb}$ and $\mathrm{Zr}$, have higher solution strengthening than Ti-6Al-4V, thus, these elements can also improve strength.

\subsection{Effect of solution temperature on microstructure and mechanical properties of $7 \mathrm{Zr}$ alloy}

Compared to Ti-6Al-4V, the tensile elongation of $7 \mathrm{Zr}$ alloys is lower at room temperature, which restricts its industrial applications. Evidence proved that the heat treatment turns out to be the most promising way to improve elongation ${ }^{[24]}$. Figure 6 shows the microstructure of $7 \mathrm{Zr}$ alloys at different 
solution temperatures and then aged at $550{ }^{\circ} \mathrm{C}$ for $4 \mathrm{~h}$. Coarse lath primary $\alpha$ and fine secondary $\alpha$ phases are formed after the solution treatment at $925{ }^{\circ} \mathrm{C}$ and $945{ }^{\circ} \mathrm{C}$, far below $\beta$-transus temperature in the $\alpha+\beta$ phase region, as indicated in Figs. 6(a) and (b). After the solution at $960{ }^{\circ} \mathrm{C}$ and $970{ }^{\circ} \mathrm{C}$, the subcritical $\beta$-transus temperature, the microstructure consists of predominantly crab-like primary $\alpha$ and a small number of fine lath secondary $\alpha$ phases and residual $\beta$ phases, as shown in Figs. $6(\mathrm{c})$ and (d). The crab-like primary $\alpha$ and the fine lath transformed $\beta$ are named bi-modal microstructure which is also found in Ti-6.5Al-3.5Mo-1.5Zr-0.3Si alloy ${ }^{[25]}$ and in Ti$6.5 \mathrm{Al}-2 \mathrm{Zr}-1 \mathrm{Mo}-1 \mathrm{~V}$ alloy ${ }^{[26]}$. Combined with the previous report ${ }^{[27]}$, the formation of bi-modal microstructure is because the $\alpha$ stabilizing element $\mathrm{Al}$ enriches in $\alpha / \beta$ phase boundary, which facilitates secondary $\alpha$ phase nucleates due to the high concentration of $\mathrm{Al}$ in the region. In addition, the $\alpha / \beta$ phase boundary at the edge of primary $\alpha$ phase is incoherent interface which has high interfacial energy, being beneficial to secondary $\alpha$ phase nucleation. Besides, the secondary $\alpha$ phases are known to form a groove by the splitting of the primary $\alpha$ laths. Furthermore, when solution at $985{ }^{\circ} \mathrm{C}$ and $995{ }^{\circ} \mathrm{C}$ over $\beta$-transus temperature in $\beta$ phase region, the length of primary $\alpha$ phases and the volume fractions of secondary $\alpha$ and residual $\beta$ phases significantly increase.
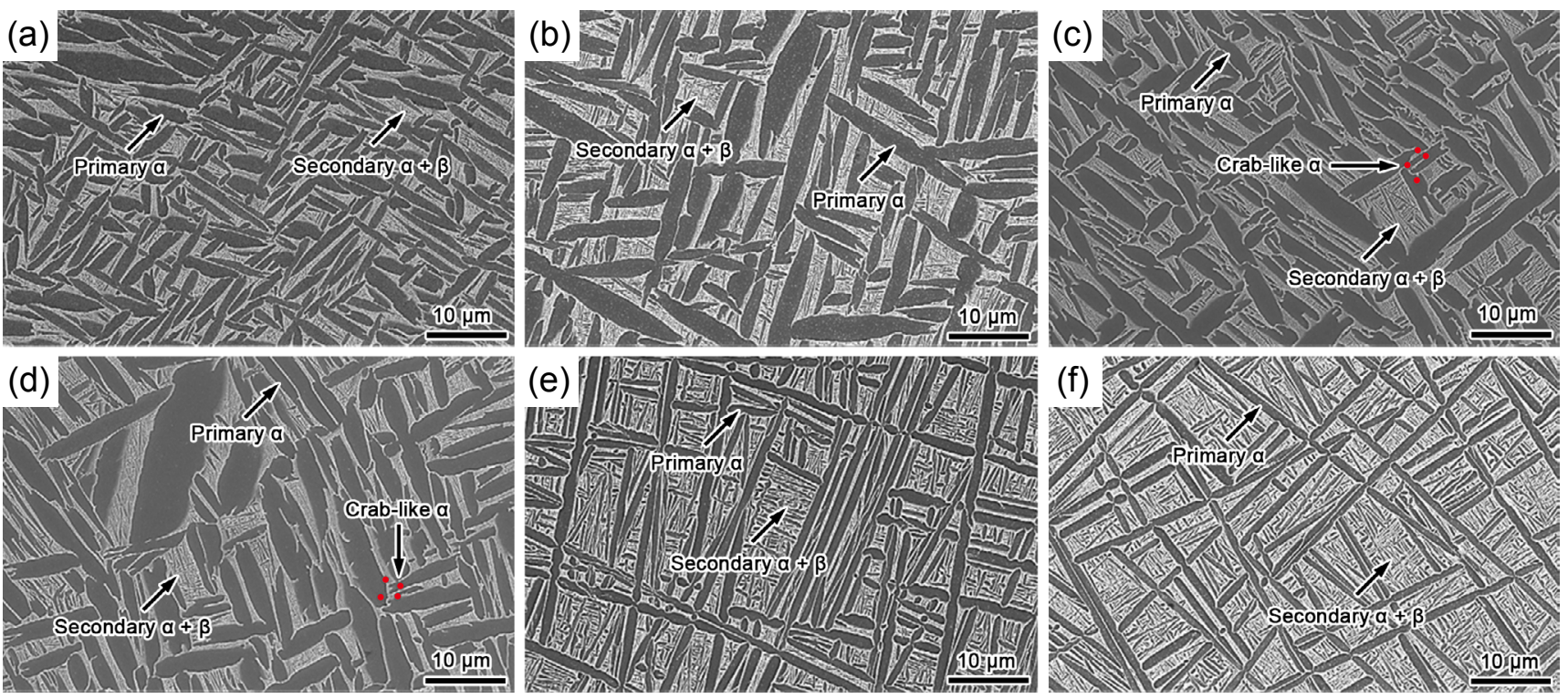

Fig. 6: Microstructures of $7 \mathrm{Zr}$ alloy at different solution temperatures and then aged at $550{ }^{\circ} \mathrm{C}$ for $4 \mathrm{~h}$ : (a) $925^{\circ} \mathrm{C}$; (b) $945^{\circ} \mathrm{C}$; (c) $960^{\circ} \mathrm{C}$; (d) $970{ }^{\circ} \mathrm{C}$; (e) $985^{\circ} \mathrm{C}$; and (f) $995^{\circ} \mathrm{C}$

Furthermore, the volume fraction and aspect ratio of primary $\alpha$ phase are counted in Fig. 7. It can be found that the volume fraction of primary $\alpha$ decreases from $33 \%$ to $23 \%$ with the increasing solution temperature from $925^{\circ} \mathrm{C}$ to $970{ }^{\circ} \mathrm{C}$. Compared with the volume fraction of primary $\alpha$ phase in the $\alpha+\beta$ phase region, the volume fraction of the primary $\alpha$ decreases rapidly to $16 \%$ in the $\beta$ phase region since the $\alpha$ phase is completely transformed into the $\beta$ phase when solution at $\beta$ phase region, as shown in Fig. 7(a). Additionally, the aspect ratio of primary $\alpha$ is sensitive to the solution temperature, as shown in Fig. 7(b). After the solution at $\alpha+\beta$ phase region, the aspect ratio of primary $\alpha$ phase decreases from $5.81 \mu \mathrm{m}$ to $2.83 \mu \mathrm{m}$. However, after the solution at $\beta$ phase region, the aspect ratio increases dramatically to $13.48 \mu \mathrm{m}$.

The micro-hardness at different solution temperatures is measured, as shown in Fig. 8. After the solution at $925^{\circ} \mathrm{C}$ and $945{ }^{\circ} \mathrm{C}$, the micro-hardness of $7 \mathrm{Zr}$ alloys is higher: $375.2 \mathrm{HV}$ and $383.7 \mathrm{HV}$, respectively. In comparison with the sample
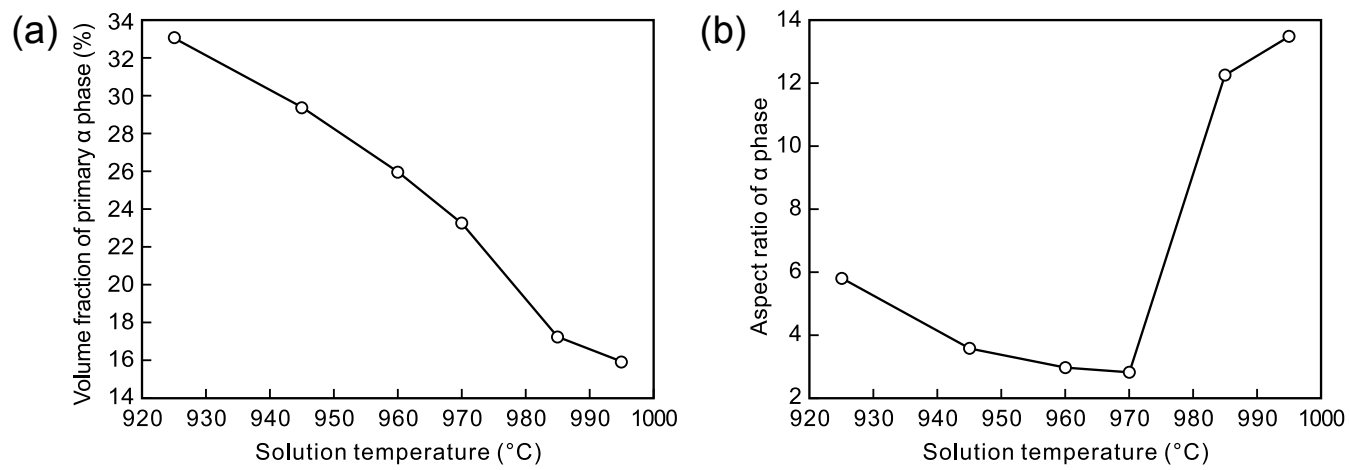

Fig. 7: Changes in volume fraction of primary $\alpha$ phase (a) and in aspect ratio of primary $\alpha$ laths (b) at different solution temperatures and then aged at $550^{\circ} \mathrm{C}$ for $4 \mathrm{~h}$ 


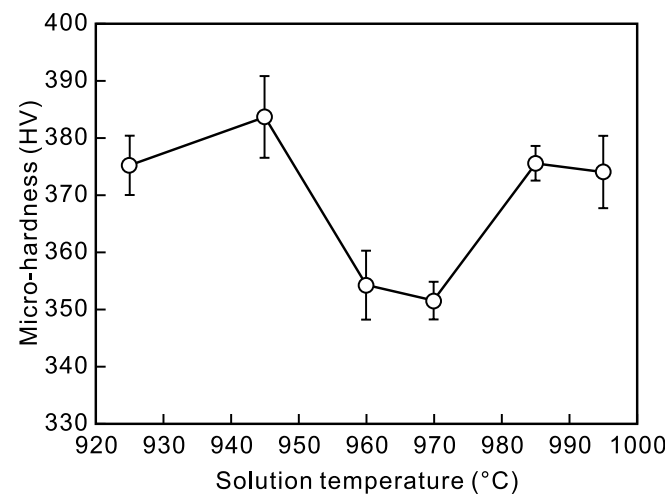

Fig. 8: Change in micro-hardness at different solution temperatures and then aged at $550^{\circ} \mathrm{C}$ for $4 \mathrm{~h}$

after the solution at $925{ }^{\circ} \mathrm{C}$ and $945^{\circ} \mathrm{C}$, the micro-hardness is dramatically dropped to $354.2 \mathrm{HV}$ and $351.5 \mathrm{HV}$ as the solution temperature increases to $960{ }^{\circ} \mathrm{C}$ and $970{ }^{\circ} \mathrm{C}$, which indicates that bi-modal microstructure can decrease microhardness. Because the width of primary $\alpha$ laths is narrower after the solution at $985^{\circ} \mathrm{C}$ and $995^{\circ} \mathrm{C}$, the micro-hardness increases to $375.6 \mathrm{HV}$ and $374.1 \mathrm{HV}$, respectively.

The true stress-strain curves of compression test samples with different solution temperatures are displayed in Fig. 9. For the $7 \mathrm{Zr}$ alloy sample after the solution at $925^{\circ} \mathrm{C}$ and $945^{\circ} \mathrm{C}$, the ultimate compression stress is $1,703.6 \mathrm{MPa}$ and 1,713.5 $\mathrm{MPa}$, and yield stress is 1,263.0 $\mathrm{MPa}$ and 1,264.5 $\mathrm{MPa}$, respectively. However, with the solution temperature increasing to $960{ }^{\circ} \mathrm{C}$ and $970{ }^{\circ} \mathrm{C}$, which is sub-critical solution temperature, the ultimate compression stress drops to 1,610.9 $\mathrm{MPa}$ and 1,624.4 $\mathrm{MPa}$, and yield stress drops to 1,171.2 $\mathrm{MPa}$ and 1,204.4 MPa, respectively. After $\beta$ solution-treated at $985^{\circ} \mathrm{C}$ and $995{ }^{\circ} \mathrm{C}$, the ultimate compression stress is $1,672.0 \mathrm{MPa}$ and 1,678.1 $\mathrm{MPa}$, and yield stress is $1,228.9 \mathrm{MPa}$ and 1,287.9 $\mathrm{MPa}$, respectively. Compared to the ultimate compression stress $(1,830.4 \mathrm{MPa})$ and yield stress $(1,365.2 \mathrm{MPa})$ of the as-deposited sample, the strength of heattreated samples dramatically drops. However, the elongation is improved after heat treatment, especially the elongation of samples with solution treatment at $960{ }^{\circ} \mathrm{C}$ and $970{ }^{\circ} \mathrm{C}$ followed by aging at $550{ }^{\circ} \mathrm{C}$ for $4 \mathrm{~h}$, which improved by $80.9 \%$ compared with as-deposited 7Zr alloy, as shown in Fig. 9(b).
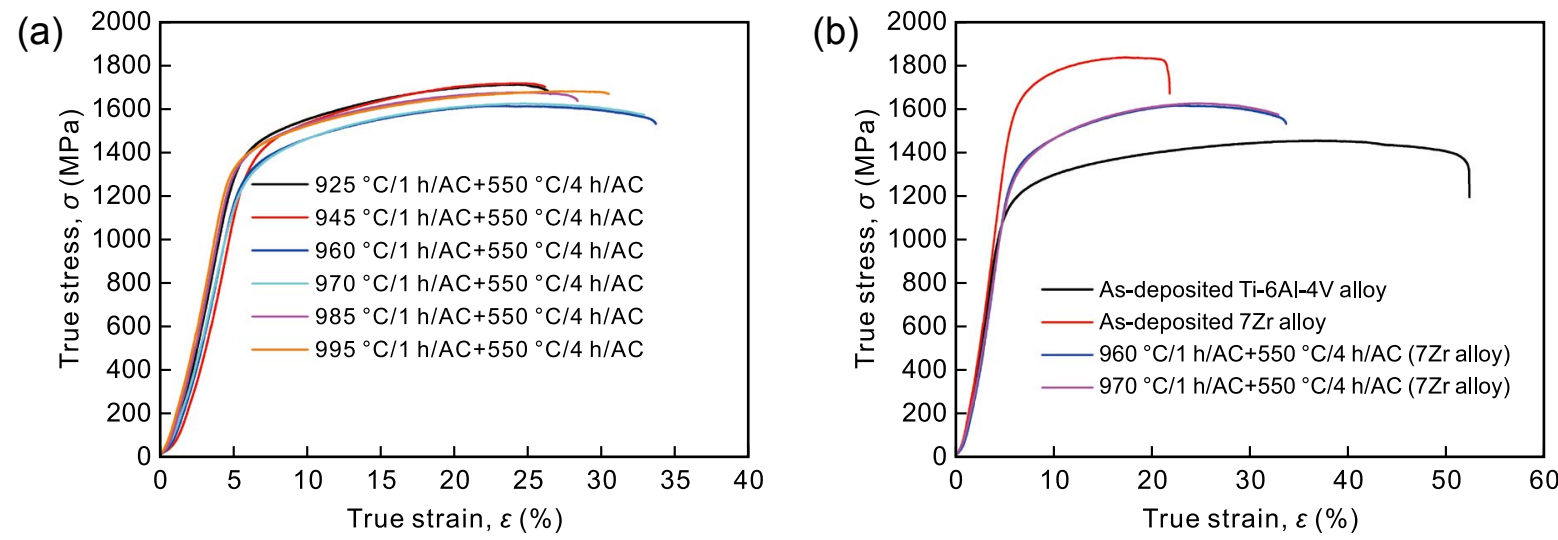

Fig. 9: True stress-strain curves of compression test samples at room temperature: (a) with different solution temperatures and aged at $550^{\circ} \mathrm{C}$ for $4 \mathrm{~h}$; (b) as-deposited and heat-treated Ti-6Al-4V and $7 \mathrm{Zr}$ alloys

In comparison with the as-deposited samples, the strength and elongation change after heat treatment, which clearly means that the microstructure features (i.e., the volume fraction, the size and shape of $\alpha$ phase) have significant influence on the mechanical properties. Ren et al. ${ }^{[15]}$ revealed that the shear bands appeared along $\alpha / \beta$ interfaces, and slip bands occurred in primary $\alpha$ laths, meaning that the strength can be improved by more $\alpha / \beta$ interfaces and decreasing the width of primary $\alpha$ laths. With the increasing solution temperature, the volume fraction of primary $\alpha$ phases gradually decreases, and the width of primary $\alpha$ phases gradually increases, leading to reduction in capacity of dislocation storage so that the strength reduces and the elongation improves.

\section{Conclusions}

The novel titanium alloy Ti-6.83Al-2.28V-2.14Mo-0.69Nb$6.79 \mathrm{Zr}$ was designed based on a cluster formula, and the microstructure and mechanical properties of as-deposited and heat-treated novel titanium alloy samples were evaluated. The main conclusions can be summarized as follows:

(1) Compared to Ti-6Al-4V, the novel alloy Ti-6.83Al2.28V-2.14Mo-0.69Nb-6.79Zr has much higher room and high temperature tensile strength, at 1,427.5 MPa and 642.2 MPa, respectively, but has much lower elongation (3.2\%) at room temperature because of the finer microstructure.

(2) The volume fraction of primary $\alpha$ decreases with the increasing solution temperature from $925{ }^{\circ} \mathrm{C}$ to $995{ }^{\circ} \mathrm{C}$. The aspect ratio of primary $\alpha$ phase decreases from $5.81 \mu \mathrm{m}$ to $2.83 \mu \mathrm{m}$ after the solution at $\alpha+\beta$ phase region. However, after the solution at $\beta$ phase region, the aspect ratio increases dramatically to $13.48 \mu \mathrm{m}$ after solution treatment at $995^{\circ} \mathrm{C}$.

(3) A unique bi-modal microstructure which contains crablike primary $\alpha$ and the fine lath transformed $\beta$ is obtained in Ti$6.83 \mathrm{Al}-2.28 \mathrm{~V}-2.14 \mathrm{Mo}-0.69 \mathrm{Nb}-6.79 \mathrm{Zr}$ alloy after the solution at $960{ }^{\circ} \mathrm{C}$ or $970{ }^{\circ} \mathrm{C}$ for $1 \mathrm{~h}$ followed by air cooling and aging at $550{ }^{\circ} \mathrm{C}$ for $4 \mathrm{~h}$ followed by air cooling, respectively, improving the elongation by $80.9 \%$ in compression testing compared to the as-deposited samples. 


\section{Acknowledgements}

This work was financially supported by the Shenyang Young and Middle-aged Scientific and Technological Innovation Talents Program (RC190490), and the Liaoning Revitalization Talents Program (No. XLYC1808030).

\section{References}

[1] Banerjee D, Williams J C. Perspectives on titanium science and technology. Acta Mater., 2013, 61(3): 844-879.

[2] Cen M J, Liu Y, Chen X. Inclusions in melting process of titanium and titanium alloys. China Foundry, 2019, 18(4): 223231.

[3] Shunmugavel M, Polishetty A, Littlefair G. Microstructure and mechanical properties of wrought and additive manufactured Ti-6Al-4V cylindrical bars. Procedia Technology, 2015, 20: 231-236

[4] Liu S Y, Shin Y C. Additive manufacturing of Ti6Al4V alloy: A review. Mater. Des., 2019, 164: 107552.

[5] Herzong D, Seyda V, Wycisk E, et al. Additive manufacturing of metals. Acta Mater., 2016, 117: 371-392.

[6] Vrancken B, Thijs L, Kruth J P, et al. Microstructure and mechanical properties of a novel titanium metallic composite by selective laser melting. Acta Mater., 2014, 68: 150-158.

[7] Mendoza M Y, Samimi P, Brice D A, et al. Microstructures and grain refinement of additive-manufactured Ti- $x \mathrm{~W}$ alloys. Metall. Mater. Trans. A., 2017, 48A: 3594-3605.

[8] Zhang $\mathrm{F}$ Y, Yang M, Clare A T, et al. Microstructure and mechanical properties of Ti-2Al alloyed with Mo formed in laser additive manufacture. J. Alloy. Compd., 2017, 727: 821-831.

[9] Zhang D Y, Qiu D, Gibson M A, et al. Additive manufacturing of ultrafine-grained high-strength titanium alloys. Nature, 2019, 576(7785): 91-95.

[10] Dong C, Wang Z J, Zhang S, et al. Review of structural models for the compositional interpretation of metallic glasses. Int. Mater. Rev., 2019, 65: 286-296.

[11] Takeuchi A, Inoue A. Classification of bulk metallic glasses by atomic size difference, heat of mixing and period of constituent elements and its application to characterization of the main alloying element. Mater. Trans., 2005, 46: 2817-2829.

[12] Liu T Y, Zhang S, Wang Q, et al. Composition formulas of Ti alloys derived by interpreting Ti-6Al-4V. Sci. China. Tech. Sci., 2021, 64: 1732-1740.

[13] Vrancken B, Thijs L, Kruth J P, et al. Heat treatment of Ti6Al4V produced by selective laser melting: Microstructure and mechanical properties. J. Alloy. Compd., 2012, 541: 177-185.
[14] Zhao Q, Chen J, Tan H, et al. Achieving superior elongation for laser solid formed extra low interstitial Ti-6AI-4V titanium alloy through equiaxial alpha microstructure. Scripta Mater., 2018, 146: $187-191$

[15] Ren $Y$ M, Lin X, Fu X, et al. Microstructure and deformation behavior of Ti-6Al-4V alloy by high-power laser solid forming. Acta Mater., 2017, 132: 82-95.

[16] Liu C M, Wang H M, Tian X J, et al. Subtransus triplex heat treatment of laser melting deposited Ti-5Al-5Mo-5V-1Cr-1Fe near $\beta$ titanium alloy. Mater. Sci. Eng. A, 2014, 590: 30-36.

[17] Mao X N, Zhang P S, Yu L L, et al. Relationship study between the component design and quenching degree for BT22 alloy. Rare. Metals. Lett., 2006, 25(6): 21-26.

[18] Abdel-Hady M, Fuwa H, Hinoshita K, et al. Phase stability change with $\mathrm{Zr}$ content in $\beta$-type Ti-Nb alloys. Scripta Mater., 2007, 57(11): 1000-1003.

[19] Carroll B E, Palmera T A, Beese A M. Anisotropic tensile behavior of Ti-6Al-4V components fabricated with directed energy deposition additive manufacturing. Acta Mater., 2015, 87: 309-320.

[20] Xu W, Brandt M, Sun S, et al. Additive manufacturing of strong and ductile Ti-6Al-4V by selective laser melting via in situ martensite decomposition. Acta Mater., 2015, 85: 74-84.

[21] A metallographic and quantitative analysis of the influence of stacking fault energy on shock-hardening in $\mathrm{Cu}$ and $\mathrm{Cu}-\mathrm{Al}$ alloys. Acta Mater., 2001, 49: 427-438.

[22] Hall E O. The deformation and ageing of mild steel: III discussion of results. Proc. Phys. Soc. Sect. B., 1951, 64: 747-753.

[23] Petch N J. The cleavage strength of polycrystals. J. Iron Steel Inst, 1953, 173: 25-27.

[24] Zhao Z, Chen J, Tan H, et al. Achieving superior elongation for laser solid formed extra low interstitial Ti-6Al-4V titanium alloy through equiaxial alpha microstructure. Scripta Mater., 2018, 146: 187-191.

[25] Lu Y, Tang H B, Fang Y L, et al. Microstructure evolution of sub-critical annealed laser deposited Ti-6Al-4V alloy. Mater. Des., 2012, 37: 56-63.

[26] Xie X X, Zhang S Q, Tang H B, et al. Effect of annealing temperatures on microstructure and mechanical properties of laser melting deposited TA15 titanium alloy. Rare Met. Mater. Eng., 2008, 37: 1510-1515.

[27] Huang A J, Li G P, Hao Y L, et al. Acicular $\alpha_{2}$ precipitation induced by capillarity at $\alpha / \beta$ phase boundaries in Ti-14Al-2Zr3Sn-3Mo-0.5Si titanium alloy. Acta Mater., 2003, 51: 4939. 